\title{
Whither those Unheard Voices? Neglected Languages of India
}

\author{
Chinchu Chithrangathan* \\ Psychologist and Research Consultant, Association for Social Change, Evolution, and Transformation (ASCENT), India
}

Submission: May 23, 2018; Published: June 25, 2018

*Corresponding author: Chinchu Chithrangathan, Psychologist and Research Consultant with Integrated Rural Technology Centre (IRTC), Palakkad, and Association for Social Change, Evolution, and Transformation (ASCENT), Kozhikode, Kerala, India, Email: chinchu.c@gmail.com

Keywords: Tribal; Language; Linguistic Anthropology; Artefacts; Unheard voices; Human history; Cornerstone; Crucial; Language; Linguistic; Cultural history; Values; Educational tools; Tribal languages

\section{Opinion}

Language has been the cornerstone of many cultural and political actions throughout human history. Apart from being an evolutionary advantage that sets humans apart from other living forms [1], language is a carrier of valuable cultural artefacts as well. The political significance of language is much more prominent and pronounced in multi-lingual societies like India. The division of the Indian union into different states was done largely on the basis of regional languages. Language as a political tool has dominated its perceptions and usage in the Indian society $[2,3]$. As a corollary of this domination of political significance, certain other aspects of the languages of India have received scant attention, more so in the academia, with only a few notable and relatively recent exceptions. An approach based on the principles and findings of linguistic anthropology is what is largely absent at present.

A number of Indian languages have been reported as on the verge of extinction. The most recent estimates by the Government agencies had pegged more than 40 languages as under threat of extinction, with less then 10,000 speakers alive. However, such conservative estimates often fail to take into consideration many crucial aspects such as the diminishing functionality of minority languages. Also, many accounts fail to count the various dialects and the tribal languages, which are more at risk of extinction. While the rights and importance of regional languages are protected by the Indian Constitution, measures for the conservation of minority languages such as those spoken by the various tribal groups have not been implemented effectively. An exception is the setting up of a Central Institute of Indian Languages in 1969. The institution has however, not been able to intervene in the matter of endangered languages so as to make notable impacts. This is true especially in the issue of using local languages as educational tools, despite evidence of minority languages as effective educational instruments [4].

Commendable efforts have been done by non-governmental movements such as the People's Linguistic Survey of India, which was able to document about 800 languages used all over India [5]. However, documentation forms only a step, albeit the most significant one, in the larger policy-level framework of action needed for the protection and futuristic development of languages at risk. What is needed in the area of minority languages of India, especially the tribal languages, is a realisation of the significance of language as a storehouse of cultural artefacts and knowledge. Studies incorporating the principles of linguistic anthropology can supply the much needed academic insight into the working of a language as an element of human development and cultural history. The way each language stores and propagates knowledge, values, and local history should form the basis for research and action, rather than the romanticized notions of preservation, which carry the risk of reducing the whole exercise into an act of charity and eventually dissipating the conservation efforts. It is also crucial that new content be created in each language, amenable to the ever-growing corpus offered by new media and the internet, thus creating visibility and utility for each language so as to ensure their survival.

\section{References}

1. Dominguez MH, Rakic P (2009) Language evolution: The importance of being human. Nature, 462(7270): 169-170.

2. Brass P (2004) Elite interests, popular passions, and social power in the language politics of India. Ethnic and Racial Studies 27(3): 353375 .

3. Sajjad M (2014) Language as a Tool of Minority Politics: Urdu, in Bihar, India, 1951-1989. Journal of Muslim Minority Affairs 34(2): 174-190. 
4. Lotz B (2004) Promoting Tribal Languages in Education: A Case Study of Santali in Orissa. Journal of Social Sciences 8(2): 129-142.

This work is licensed under Creative Commons Attribution 4.0 License

DOI: 10.19080/GJAA.2018.04.555652
5. Devy GN (2014) The Being of Bhasha: A General Introduction (1 $1^{\text {st }}$ edn), Permanent Black/Orient BlackSwan, New Delhi, India.

\section{Your next submission with Juniper Publishers will reach you the below assets}

- Quality Editorial service

- Swift Peer Review

- Reprints availability

- E-prints Service

- Manuscript Podcast for convenient understanding

- Global attainment for your research

- Manuscript accessibility in different formats

( Pdf, E-pub, Full Text, Audio)

- Unceasing customer service

Track the below URL for one-step submission https://juniperpublishers.com/online-submission.php 